\title{
THE EFFECT OF CREDIT RISK MANAGEMENT ON PROFITABILITY: AN EMPIRICAL STUDY OF PRIVATE BANKS IN SYRIA
}

\author{
Allam Yousuf ${ }^{\star *}$, János Felföldi ${ }^{2}$ \\ ${ }^{1}$ Károly Ihrig Doctoral School of Management and Business, University of Debrecen, \\ Debrecen, Hungary \\ ${ }^{2}$ Logistics Department, Faculty of Economics and Business, University of Debrecen, \\ Debrecen, Hungary \\ allamyousuf@yahoo.com \\ felfoldi.janos@econ.unideb.hu
}

\begin{abstract}
The objective of this study is to investigate the effect of credit risk management on profitability in private banks in Syria. Two main criteria have been adopted for the management of credit risk in banks: capital adequacy ratio and non-performing loans. In order to achieve the objectives of the research and to test the hypotheses, an appropriate non-probability sample numbering 6 private banks was selected from those private banks in Syria for which financial reports and risk management reports were available sequentially from 2007 until 2011, because the researchers wanted to investigate the relationship between variables within normal conditions not in the light of instability in Syria. Credit risk was measured by the capital adequacy ratio (CAR), and non-performing loans (NPL), whereas profitability was measured by the ROE indicator by calculating the data and financial reports of sampled banks and showing them in a quantitative manner and identifying the relationship between the variables by using the SPSS program to study the correlation and build the regression equation. The study concluded that there is a statistically significant relationship between capital adequacy and profitability, the capital adequacy ratio affects profitability negatively. Non-performing loans do not effect profitability (ROE). In general, credit risk management accounts for $19 \%$ of the profitability of banks.
\end{abstract}

Key words: Credit risk management, Capital adequacy ratio (CAR), Non-performing loans (NPL), profitability, Returns on equity (ROE), Private banks in Syria.

JEL classification: G32, G21.

\section{Introduction}

Credit activity is considered to be very important for the success of financial and banking institutions because the results of their business depend mainly on the quality and size of their credit portfolio and therefore these institutions must direct most of their resources to manage and monitor their credit portfolio. As a result of the extensive expansion of banking activity at the international level, the need has emerged for standards which can be used in banking and finance internationally, to ensure a degree high level of international financial stability in a competitive environment. This is what flagged the way for the emergence of Basel Committee on Banking Supervision (BCBS) working under the Bank of International Settlements in Basel, Switzerland. The committee is named the "Basel Committee" (BIS) and makes its recommendations to the Basel Committee on Banking Supervision. According to Zou and $\mathrm{Li}$ (2014) in commercial banks credit risk management has positive effects on profitability. Olokoyo (2011) reported that lending represented the main activity of the

\footnotetext{
${ }^{*}$ Corresponding author: Allam, Yousuf
} 
banking industry. Often, bank managers encounter the problem of trying to increase credit volumes while decreasing the possibility of default (Huang et al, 2007). Credit risk management is regarded as an approach which controls and manages uncertainties through risk assessment and improves strategies to reduce risks by using managerial resources (Afiriyie and Akotey, 2013). Achou and Tengue (2008) clarified the idea that good credit risk management will lead to good banking performance. They reasoned that it is very important for banks to apply wise credit risk management to protect both the assets of the bank and protect investor's interest".

The banking sector is one of the strategic pivotal sectors in the economic development process in Syria, and banking services are provided by the public and private banks. Moreover, the Central Bank of Syria manages the entire financial process of the country. Prior to 2000, the banking system was a government monopoly in which, commercial banks were all government owned. After 2000, however, Syria witnessed a shift towards an open economy and allowed the private sector to invest in the banking sector and financial institutions; as a result, the first commercial private bank (IBTF) started operating in 2003. Private banks in Syria, despite their limited experience, started to grow naturally at a much faster pace than the government banks that had completely controlled the market before 2000. The share of private banks in the total assets of the financial sector in Syria increased from $13 \%$ at the end of 2007 and reached $30.4 \%$ by the end of 2011 .

Despite that, there are many questions and doubts about the standards which are applied by these banks to manage their credit risks and reduce the ratio of non-performing loans, in order to avoid the problem which has previously faced governmental banks. We can summarize the research problem through the following questions: firstly, how does capital adequacy affect profitability? Secondly, how do non-performing loans affect profitability?

\section{Literature review}

\subsection{Credit risk management}

Basel I and II are regarded as significant reform which has been carried out in the banking sector following banking crises; they refer to the banking supervision accords issued by the Basel Committee on Banking Supervision (BCBS). Basel (I) is also known as the 1988 Basel Accord, which implemented a framework for a minimum capital standard of $8 \%$ for banks (Hosna et al, 2009). The aim of the Basel II standards was to avoid the weakness of Basel I by creating a strong foundation for prudent capital regulation, supervision, and market control, and enhancing risk management and financial stability (BCBS, 2004).

Basel I is considered a tool to measure the capital to risk weighted-asset ratio (CRAR). It defines a bank's capital as two types: core (or Tier I), and supplementary (or Tier II). According to Basel I, at least 50 percent of a bank's capital base should consist of core capital. Basel II is more than a comprehensive framework of banking supervision, since it also includes got provisions for supervisory review and market control.

Basel II includes three basic criteria: firstly, minimum regulatory capital (Pillar 1) where CRAR is calculated by incorporating credit, market and operational risks. Secondly, supervisory review (Pillar 2) provides key principles for supervisory review, risk management guidance and supervisory transparency and accountability. Thirdly, market control (Pillar 3 ) encourages market control by improving a group of exposure requirements that will enable market participants to evaluate information on risk exposure, risk assessment processes and the capital adequacy of a bank.

\subsubsection{Capital Adequacy ratio}

According to Alfon et al, (2004) there are three categories for determining the CAR (Capital Adequacy Ratio): firstly, banks' internal policies and considerations. Secondly, market 
forces, and thirdly, regulatory requirements. Bokhari et al (2012) clarified the concept that in the banking system alternative capital cost is regarded as major component of Capital Adequacy Ratio (CAR). In addition, Return on Equity (ROE) is a more suitable tool for the analysis of the alternative cost of capital when the cost of capital is low. As the rate of the alternative cost of capital increases, there is a willingness to reduce the holdings of extra capital. As indicated by Sinkey (1992), regulators utilize the CAR as an important measure both "safety and soundness" of depository institutions because they regard as capital a safety margin capable of absorbing possible losses. There are two proposed types of capital ratios. The first relates to Tier 1 capital, which must absorb the losses of the bank without leading to a cessation of activities. The second is Tier 2 capital, usually subordinated debt, which is aimed at ingesting losses in the event of liquidation and thus provides a small degree of depositors. In this study, we use the CAR formula based on both Tier 1 and Tier 2 capital. According to Anbar and Alper (2011) capital adequacy (like other factors such as asset size, asset quality, liquidity, deposit and income-expenditure structure) is considered a bank- specific determinant as internal factors are determined by the bank's management decisions and policy objectives. Anbar and Alper (2011) reported that capital adequacy as a ratio of equity to total assets $(\mathrm{CA})$ is considered one of the basic ratios for capital strength. It is expected that the increase in this ratio will lead to decrease in the need for external funding and an increase in the profitability of the bank. It clarifies the bank's ability to ingest losses and handle risk exposure with shareholders. According to Lin et al (2005) capital adequacy is one of the common indicators in the warning system used by financial officials and has slowly been given more weight in many countries throughout the world. Currently, $8 \%$ capital adequacy represents the lowest standard with regard to the risk of failure. As the rate increases, a bank's stability and security increase. It is only after a bank has reached the standard for security and has begun to turn profits, that the capital adequacy figure has any meaning.

\subsubsection{Non-performing loans}

In a context of rapid economic progress, financial stability is considered a cornerstone of general economic well-being. Banks' non-performing loans as an indicator of financial stability are very important because they reflect the asset quality, the credit risk and the efficiency of the allocation of resources to productive sectors (Rajan and Dhal, 2003). According to the literature, there are two groups of factors to explain the evolution of non-performing loans (NPLs) over time. The first group dealing with the overall macroeconomic conditions focuses on external events which affect the borrowers' capacity to repay their loans, whereas, the second group takes in consideration the variability of NPLs across banks, and ascribes the level of non-performing loans to bank-level factors ( Klein , 2013). There are strong correlations between NPLs and numerous macroeconomic (public debt, unemployment, annual percentage growth rate of gross domestic product) and bank-specific factors (capital adequacy ratio, rate of nonperforming loans of the previous year and return on equity) (Makri et al, 2014). The ratio of (NPLs) considered one of the most important pointers used to identify credit risk (Makri et al, 2014). Many researchers consider NPLs as "financial pollution", with harmful effects for both economic development and social welfare (Gonzales, 1999; Barseghyan, 2010; Zeng, 2012). According to Bercoff et al (2002), the NPLs rate is influenced equally by bank-specific factors including asset growth, operating costs to asset ratio, institutional characteristics relating to private and foreign banking, and macroeconomic factors, such as credit growth, foreign interest rates, and monetary expansion etc. According to Louzis et al (2012), the determinants of NPLs, are either macroeconomic or bank-specific determinants (but not both) and are used as illustrative variables. 


\section{Profitability}

There are many measurements of a bank's performance, and profitability is considered one of the most important criteria (Anbar and Alper, 2011). In addition to this, profitability as a measurement of performance includes both accounting and operations-based measures: (1) return on assets (ROA), (2) return on equity (ROE), (3) return on sales (ROS), and (4) sales growth (SG) (Qian and Li, 2003). (Colquitt, 2007) clarified the purpose of ROE as the measurement of the amount of profit generated by the equity in the firm; the (ROE) "return on equity ratio" shows the return which owners receive in return for investing their funds in the bank, and is considered one of the most important profitability ratios, influencing the decisions of the owners to continue their investment in the bank or transfering their investments to other activities with suitable yields. Anbar and Alper (2011) show that cleared that ROE is net profit divided by shareholders' equity and is expressed as a percentage. It explains the extent to which the bank was successful and efficient in investing its funds, as the increase in the bank's profits will maximize bank share values at (ASE), which will affect the bank's financial security. In addition to this, Molyneux and Thornton (1992) noted that there is a direct relationship between return on equity and capital adequacy.

\section{Methodology}

The aim of this paper is to investigate the relationship between credit risk management (capital adequacy and non-performing loans) and profitability (ROE) in commercial private banks in Syria.

Secondary data: annual reports issued by private banks and certified by the Syrian financial market are used to obtain the required financial ratios. Many researchers have investigated the relationship between credit risk management and profitability, including (Gizaw et al, 2015; Hosna et al, 2009; Zou and Li, 2014).

The target population is private banks in Syria, and the sample consists of commercial private banks only (non-Islamic banks), because of the differences in standards and regulations which affect the operational policies of Islamic banks. Islamic banking system and commercial banking system are different as the Islamic banking system pursues Profit and Loss (PLS) paradigm. Because of PLS paradigm, the bank and depositors/borrowers share profit (Mudarabah) and loss (Musyarakah) with each other (Zulfiqar, 2016 ; Chong and Liu, 2009).

The sample is consisted of six commercial banks (Bank of Syria and Overseas BSO, International Bank for Trade and Finance IBTF, Banque Bemo Saudi Fransi BBSF, Bank Audi, Byblos Bank and Arab Bank).The study covered a past five years which is started from 2007 to 2011, before the war in Syria, The study shows the normal situation for the country with peace, Moreover because it aimed to investigate the relationship between variables in normal conditions in order to achieve more accurate results.

\section{Descriptive analysis:}

According to Appendix (A):

Table 1: Mean and Standard deviation of the variables

Source: Author's own calculations

\begin{tabular}{|l|c|c|}
\hline Variable & Mean & SD \\
\hline CAR & $15.09 \%$ & 0.04 \\
\hline NPL & $3.1 \%$ & 0.035 \\
\hline ROE & $10.54 \%$ & 0.046 \\
\hline
\end{tabular}


The mean value of CAR $=(15.09 \%)$ for the six banks, this ratio exceeds the average of the minimum determined by the Basle Committee, which approved by the Central Bank of Syria, we can consider that as an indicates of commitment of banking sector for this standard. The value of standard deviation was (0.04) and this indicates that there is no significant dispersion of the capital adequacy rate values. The mean value of NPLR is (0.031) with a stander deviation (0.035). This is indicative of the convergence of the ratio of non-performing loans in the six banks. The mean value of $(\mathrm{ROE})=10.54 \%$ and the standard deviation $=$ 0.046

\section{Statistical analysis}

Table 2: Correlation matrix between variables

\begin{tabular}{|c|c|c|c|c|}
\hline Variables & Correlation & CAR & ROE & NPL \\
\hline \multirow{2}{*}{ CAR } & Pearson Correlation & \multirow{2}{*}{1} & $-.443\left(^{*}\right)$ & $.475\left({ }^{* *}\right)$ \\
\hline & Sig. (2-tailed) & & .014 & .008 \\
\hline \multirow{2}{*}{ ROE } & Pearson Correlation & $-.443\left(^{*}\right)$ & \multirow{2}{*}{1} & -.211 \\
\hline & Sig. (2-tailed) & .014 & & .262 \\
\hline \multirow{2}{*}{ NPL } & Pearson Correlation & $.475\left(^{* *}\right)$ & -.211 & \multirow{2}{*}{1} \\
\hline & Sig. (2-tailed) & .008 & .262 & \\
\hline
\end{tabular}

${ }^{* *}$ Correlation is significant at the 0.01 level (2-tailed).

${ }^{*}$ Correlation is significant at the 0.05 level (2-tailed).

Source: Author's own calculations

The Person correlation is used to find the degree of correlation between variables. According to the correlation matrix, there is a moderate negative correlation (-44\%) between profitability (ROE) and (CAR), at a significant level (95\%). There is a weak negative correlation (-21\%) between profitability (ROE) and (CAR). There is a moderate correlation between independent variables (CAR \& NPLR) (correlation value $=47 \%$ ) at a significant level (95\%).

\section{Hypotheses test:}

\section{Research hypotheses}

$\mathrm{H} 1$ : There is a statistically significant relationship between Non-performed loans and profitability (ROE) at a $\leq 0.05$.

$\mathrm{H} 2$ : There is a statistically relationship between CAR effects on profitability (ROE) at $a \leq 0.05$.

Table 3 Anova test (Model Summary)

\begin{tabular}{|c|c|c|c|c|}
\hline Model & $\mathbf{R}$ & R Square & $\begin{array}{c}\text { Adjusted R } \\
\text { Square }\end{array}$ & $\begin{array}{c}\text { Std. Error of the } \\
\text { Estimate }\end{array}$ \\
\hline 1 & $.443(\mathrm{a})$ & .196 & .137 & .043520010883897 \\
\hline
\end{tabular}

a Predictors: (Constant), NPLR, CAR

b Dependent Variable: ROE

Source: Author's own calculations

According to the previous table, we can note that independent variable credit risk management (CAR \& NPL) correlates to the dependent variable (ROE), and credit risk management explains $13.7 \%$ of the change in ROE. 
Oradea Journal of Business and Economics, Volume III, Issue 2

Published on September 2018

Table 4 Liner regression test (Coefficients)

\begin{tabular}{|c|c|c|c|c|c|}
\hline \multirow{2}{*}{ Model } & \multicolumn{2}{|c|}{ Unstandardized Coefficients } & Standardized Coefficients & \multirow{2}{*}{ Sig. } \\
\cline { 2 - 5 } & $\mathbf{B}$ & Std. Error & Beta & & \\
\hline 1 & .180 & .031 & - & 5.822 & .000 \\
\hline CAR & -.491 & .217 & -.442 & -2.257 & .032 \\
\hline NPL & -.002 & .261 & -.001 & -.008 & .994 \\
\hline
\end{tabular}

a Dependent Variable: ROE

Source: Author's own calculations

From the previous table we can arrive at the regression equation:

$\mathrm{ROE}=\alpha 1+\beta 1 \mathrm{NPLR}+\beta 2 \mathrm{CAR}$

$\mathrm{ROE}=0.180-0.002 \mathrm{NPLR}-0.491 \mathrm{CAR}$

Firstly: effects of non-performing loans on profitability

The NPLs ratio negatively effects ROE, (B for NPL $=0.002)$, which means every increase in NPLs is accompanied by a decrease in profitability (ROE) $(=0.002)$, with a constant of CAR. It is a negative relationship which, we can state is related to the lack of experience in credit risk management of these banks, either because of its novelty in Syrian markets or because they gave loans without sufficient guarantees. The Sig. is $(0.994)>0.05$, so there is no significant relation between NPLs and ROE, and consequently we refuse H.1: there is a statistical relationship between Non-performed and profitability (ROE).

Secondly: CAR negatively effects profitability $(\mathrm{ROE})$. B for $\mathrm{CAR}=(-0.491)$, which means every increase in CAR meet is accompanied by a decrease in ROE of (0.491). The Sig. is $(0.032)<0.05$ which means there is a significant relationship between (CAR and ROE) at a confidence level of $95 \%$, and we accept $\mathrm{H} 2$ : There is a statistical relationship between CAR effects on profitability (ROE). We can note that the relationship has negative effects, which means an increase in the CAR ratio gives the best protection for depositors, and meets central bank regulations which agree with Basel standards. However, at the same time it leads to reduction ROE and this effects shareholder negatively, it was clear that private banks sought to increase CAR, but this procedure had negative effects on ROE.

\section{Results}

There is a statistically significant relationship between capital adequacy and profitability $(\mathrm{ROE})$. The capital adequacy ratio affects profitability negatively. Credit risk management accounts for $13.7 \%$ of the profitability of banks. Non-performing loans do not effect profitability (ROE). The mean of the capital adequacy ratio for all banks reached $15.09 \%$ with a standard deviation of 0.04 and thus exceeded the minimum rate set by the Basel Committee; the minimum value was $8.42 \%$ at BIMO Bank in 2007, while it reached $25.24 \%$ in the Arab Bank in 2011.Banks in the study sample recorded a profit of $10.54 \%$ with a standard deviation of 0.046 . The highest value of ROE was $19.43 \%$ in 2007 at Banque Bemo Saudi Fransi (BBFS) and the minimum was 1.38\% at Byblos Bank in 2007.

The minimum value for CAR was (8.42\%) In 2007 at Banque Bemo Saudi Fransi, while some value of CAR ratio reached (25.24\%) at Arab Bank in 2011.

The highest value of (NPLR) $=0.14$ at Banque Bemo Saudi Fransi in 2011, that is indicating for a weak credit risk management at that bank comparing than other banks in the sample. We can note there is a similarity in ROE for all the banks (six banks) during period of the study. Except Banque Bemo Saudi Frans (ROE = 19.34\%) in 2007, but that average started to decrease till (9\%) in 2011, with increase of NPLR till 14\% in 2011. 


\section{Conclusion}

We recognize the importance of balancing attempts to raise the capital adequacy rate and maintaining the profitability of the bank. The increase in the capital adequacy ratio means achieving better protection for depositors and meeting the Central Bank's requirements in order to comply with the Basel's requirements. However, this leads to a decrease in the rate of return on equity, thereby harming shareholders. Establishing sound credit criteria includes carrying out continuous evaluation, selecting customers, inquiring about their financial quality, granting them the appropriate credit for their activity and diversifying the selection of customers from different sectors, in order to maintain a low level of non-performing loans and keep them within acceptable limits in order to minimize their impact on profitability.

Keeping abreast of international banking developments in terms of capital adequacy standards, liquidity ratios, credit worthiness and the principle of financial transparency, and issuing a new package of laws commensurate with modern banking will give greater flexibility to banks and ensure banking expertise, thus significantly enhancing the competitiveness of Syrian banks as well as increasing confidence of foreign investors.

\section{References}

Achou, F.T. and Tegnuh, N.C., 2007. Bank Performance and Credit Risk Management. Master Degree Project School of Technology and Society. University of Skovde Press.

Afiriyie, H. and Akotey, D.O., 2013. Credit risk management and profitability of rural banks in the brong Ahafa region of Ghana. European Journal of Business and Management, 5(24), pp.24-33.

Alfon, I., Argimon, I. and Bascuñana-Ambrós, P., 2004. What determines how much capital is held by UK banks and building societies?. London: Financial Services Authority.

Anbar, A. and Alper, D., 2011. Bank specific and macroeconomic determinants of commercial bank profitability: Empirical evidence from Turkey. Business and Economics Research Journal, 2(2), pp. 139-152, .

Barseghyan, L., 2010. Non-performing loans, prospective bailouts, and Japan's slowdown. Journal of Monetary Economics, 57(7), pp.873-890.

Basel Committee on Banking Supervision. "Implementation of Basel II: Practical Considerations". July 2004, http://www.bis.org/publ/bcbs109.htm [Accessed 11_June 2018] Bercoff, J.J., Giovanni, J. and Grimard, F., 2002. Argentinean banks, credit growth and the Tequila crisis: A duration analysis. Unpublished Paper.

Bokhari, I.H., Ali, S.M. and Sultan, K., 2012. Determinants of capital adequacy ratio in banking Sector: An Empirical analysis from Pakistan. Academy of Contemporary Research Journal, 2(1), pp. 1-9.

Chong, B.S. and Liu, M.H., 2009. Islamic banking: interest-free or interest-based? PacificBasin Finance Journal, 17(1), pp.125-144

Colquitt, J., 2007. Credit risk management: How to avoid lending disasters and maximize earnings. McGraw Hill Professional.

Gizaw, M., Kebede, M. and Selvaraj, S., 2015. The impact of credit risk on profitability performance of commercial banks in Ethiopia. African Journal of Business Management, 9(2), pp. 59-66.

González-Hermosillo, B., 1999. Developing indicators to provide early warnings of banking crises. Finance and Development, 36, pp.36-39.

Huang, C.L., Chen, M.C. and Wang, C.J., 2007. Credit scoring with a data mining approach based on support vector machines. Expert systems with applications, 33(4), pp.847-856.

Hosna, A., Manzura, B. and Juanjuan, S., 2009. Credit risk management and profitability in commercial banks in Sweden. Master Degree Project 2009: 36., Available at: https://gupea.ub.gu.se/handle/2077/20857 [Accessed 11 June 2018] 
Klein, N., 2013. Non-performing loans in CESEE: Determinants and impact on macroeconomic performance. International Monetary Fund. (w/p:No. 13-72).

Lin, S.L., Penm, J.H., Gong, S.C. and Chang, C.S., 2005. Risk-based capital adequacy in assessing on insolvency-risk and financial performances in Taiwan's banking industry. Research in International Business and Finance, 19(1), pp.111-153.

Louzis, D.P., Vouldis, A.T. and Metaxas, V.L., 2012. Macroeconomic and bank-specific determinants of non-performing loans in Greece: A comparative study of mortgage, business and consumer loan portfolios. Journal of Banking \& Finance, 36(4), pp.1012-1027. Makri, V., Tsagkanos, A. and Bellas, A., 2014. Determinants of non-performing loans: The case of Eurozone. Panoeconomicus, 61(2), pp.193-206

Molyneux, P. and Thornton, J., 1992. Determinants of European bank profitability: A note. Journal of Banking \& Finance, 16(6), pp.1173-1178.

Olokoyo, F.O., 2011. Determinants of commercial banks' lending behavior in Nigeria. International Journal of Financial Research, 2(2), pp.61-72.

Qian, G. and Li, L., 2003. Profitability of small-and medium-sized enterprises in high-tech industries: the case of the biotechnology industry. Strategic Management Journal, 24(9), pp.881-887.

Rajan, R. and Dhal, S.C., 2003. Non-performing loans and terms of credit of public sector banks in India: An empirical assessment. Occasional Papers, 24(3), pp.81-121.

Jr Sinkey, J.F. and Sinkey Jr, J.F., 1992. Commercial bank financial management: in the financial-services industry. $6^{\text {th }}$ ed. Prentice Hall

Zeng, S., 2012. Bank non-performing loans (NPLS): A dynamic model and analysis in China. Modern Economy, 3(01), pp.100-110.

Zou, Y. and Li, F., 2014. The Impact of Credit Risk Management on Profitability of Commercial Banks: A Study of Europe. Master thesis, Umeå School of Business and Economics.

Zulfiquar, S., Haddad, H., Al-Shehhi, Y. and Máté, D., 2016. Financial performance of Islamic bank in the United Arab Emirates, Pakistan and Jordan: A case comparative study with Dupont Approach. The Annals of The University of Oradea. Economic Sciences, TOM XXV, 2nd Issue, pp.403 - 409.

\section{Bio-note}

Yousuf Allam, is a PhD candidate at Logistics Department, Károly Ihrig Doctoral School of Management and Business, University of Debrecen in Hungary. Allam as $\mathrm{PhD}$ researcher interested in management and financial studies in medium and small companies, and conducted many researches focused on flexibility, uncertainty and risk management.

János Felföldi, is associated professor and head of Logistics Department, Károly Ihrig Doctoral School of Management and Business, University of Debrecen in Hungary. His research field inculdes business and management. 


\section{Appendix (A):}

Table 5 Financial Ratios

\begin{tabular}{|l|c|c|c|c|}
\hline \multicolumn{1}{|c|}{ Bank } & Year & CAR & NPLR & ROE \\
\hline IBTF & 2007 & 0.1662 & 0.001081189 & 0.112280366 \\
\hline IBTF & 2008 & 0.1567 & 0.000808062 & 0.138579351 \\
\hline IBTF & 2009 & 0.1161 & 0.004220009 & 0.177953582 \\
\hline IBTF & 2010 & 0.1738 & 0.008761139 & 0.124940191 \\
\hline IBTF & 2011 & 0.2274 & 0.046355915 & 0.128893317 \\
\hline Arab Bank & 2007 & 0.2101 & 0.003110928 & 0.087946626 \\
\hline Arab Bank & 2008 & 0.2022 & 0.018038232 & 0.081883843 \\
\hline Arab Bank & 2009 & 0.1927 & 0.043823946 & 0.055071014 \\
\hline Arab Bank & 2010 & 0.1612 & 0.064317424 & 0.110512623 \\
\hline Arab Bank & 2011 & 0.2524 & 0.108274408 & 0.077476441 \\
\hline Byblos Bank & 2007 & 0.1574 & 0.006149709 & 0.013829408 \\
\hline Byblos Bank & 2008 & 0.1116 & 0.009866201 & 0.092661661 \\
\hline Byblos Bank & 2009 & 0.0844 & 0.007605057 & 0.076818809 \\
\hline Byblos Bank & 2010 & 0.1326 & 0.013003947 & 0.052664939 \\
\hline Byblos Bank & 2011 & 0.1796 & 0.043262762 & 0.025809689 \\
\hline BBFS & 2007 & 0.0842 & 0.023668413 & 0.194369449 \\
\hline BBFS & 2008 & 0.124 & 0.021207262 & 0.189489706 \\
\hline BBFS & 2009 & 0.1146 & 0.058420096 & 0.150041865 \\
\hline BBFS & 2010 & 0.1227 & 0.068858265 & 0.131618056 \\
\hline BBFS & 2011 & 0.185 & 0.140884486 & 0.093934394 \\
\hline BSO & 2007 & 0.1232 & 0.016062386 & 0.068593268 \\
\hline BSO & 2008 & 0.1163 & 0.009354071 & 0.163791066 \\
\hline BSO & 2009 & 0.1311 & 0.017578661 & 0.144690498 \\
\hline BSO & 2010 & 0.1193 & 0.009563389 & 0.139271503 \\
\hline BSO & 2011 & 0.1448 & 0.05609434 & 0.10103972 \\
\hline Bank Audi & 2007 & 0.124 & 0.017068436 & 0.092069894 \\
\hline Bank Audi & 2008 & 0.0958 & 0.033654725 & 0.119215768 \\
\hline Bank Audi & 2009 & 0.1534 & 0.023759829 & 0.101889586 \\
\hline Bank Audi & 2010 & 0.1648 & 0.033548695 & 0.0993094 \\
\hline Bank Audi & 2011 & 0.2018 & 0.094175337 & 0.016418396 \\
\hline
\end{tabular}

Source Author's own calculations depending on Damascus Securities Exchange reports

IBTF: International Bank for Trade \& Finance

BBFS: Banque Bemo Saudi Fransi

BSO: Bank of Syria and Overseas 